\author{
Maryna Lohvynova \\ PhD Student of the Department of Human Geography and Regional Studies \\ e-mail: logvinova_mari94@ukr.net, ORCID ID: https://orcid.org/0000-0003-3190-710X \\ V.N. Karazin Kharkiv National University, Svobody Sq., 4, Kharkiv, 61022, Ukraine
}

\title{
TO THE METHODOLOGY OF SOCIO-GEOGRAPHICAL RESEARCH OF THE INTERNAL DISPLACEMENT OF THE POPULATION
}

In this article, the author analyzes the approaches and methods of studying migration processes, in particular, forced internal displacement of the population. The analysis of foreign and domestic literature showed that domestic researchers of migration processes use traditional methods and approaches, while foreign scientists use interdisciplinary tools of approaches and methods. For a comprehensive socio-geographical study, it is necessary to combine traditional industry and interdisciplinary methods, which will reveal the real extent of forced internal displacement of the population at the regional and national levels. In addition, the use of this technique will allow conducting qualitative or quantitative studies of migrations, assessing the scale of migration processes, and revealing the structural and dynamic characteristics of migrants.

To study the internal population displacement, the author suggests using the following approaches: geographical, systemic, synergetic, informational, historical, demographic, economic, legal, sociological, psychological, individual. The author considers the use of traditional methods of socio-geographical research of migration processes. Of great importance are philosophical and general scientific methods, in particular analysis and synthesis, induction and deduction, observation, abstraction, and others. The necessity of using sociological and mathematical-statistical methods is substantiated. In this case, depending on the type of data collected, use qualitative (coding or content analysis) or quantitative (statistical methods: regression, descriptive statistics or modeling of structural equations) methods. The effectiveness of research on migration processes is enhanced by mathematical methods, in particular modeling. The following types of models are used in forecasting migration processes: open or closed models; discrete or continuous models; deterministic or stochastic models. The most effective, in our opinion, is the G. Zipf gravity model, as well as various types of regression models.

Keywords: method, sociological methods, modeling of migration processes, migration, forced migration, socio-geographical research.

Марина Логвиова. ДО МЕТОДИКИ СУСПІЛЬНО-ГЕОГРАФІЧНОГО ДОСЛІДЖЕННЯ ВНУТРІШНЬОГО ПЕРЕМІЩЕННЯ НАСЕЛЕННЯ

У даній статті автором проведений аналіз підходів та методів дослідження міграційних процесів, зокрема, вимушеного внутрішнього переміщення населення. Проаналізувавши зарубіжну і вітчизняну літературу, виявлено, що вітчизняні дослідники міграційних процесів користуються традиційними методами і підходами, в той час як зарубіжні вчені використовують міждисциплінарний інструментарій підходів і методів. Для комплексного суспільно-географічного дослідження необхідно поєднувати традиційні галузеві та міждисциплінарні методики, що дозволить виявити реальні масштаби вимушеного внутрішнього переміщення населення на регіональному та національному рівнях. Крім того, використання даної методики дозволить провести якісні або кількісні дослідження міграцій, оцінити масштаби міграційних процесів і виявити структурно-динамічні особливості мігрантів.

Для дослідження внутрішнього переміщення населення автор пропонує використовувати такі підходи: географічний, системний, синергетичний, інформаційний, історичний, демографічний, економічний, юридичний, соціологічний, психологічний, індивідуальний. Автором розглянуто використання традиційних методик суспільно-географічного дослідження міграційних процесів. Важливе значення мають філософські і загальнонаукові методи, зокрема, аналіз і синтез, індукція і дедукція, спостереження, абстрагування та інші. Обгрунтовано необхідність використання соціологічних та математикостатистичних методів. При цьому в залежності від типу зібраних даних, використовують якісні (кодування або контентаналіз) або кількісні (статистичні методи: регресія, описова статистика або моделювання структурних рівнянь) методи. Ефективність дослідження міграційних процесів підвищують математичні методи, зокрема моделювання. У прогнозуванні міграційних процесів використовують такі види моделей: відкриті або закриті моделі; дискретні або безперервні моделі; детерміновані або стохастичні моделі. Найбільш ефективною, на наш погляд, є гравітаційна модель Дж. Зіпфа, а також різні види регресійних моделей.

Ключові слова: метод, соціологічні методи, моделювання міграційних процесів, міграція, вимушена міграція, суспільно-географічне дослідження.

\footnotetext{
Марина Логвинова. К МЕТОДИКЕ ОБЩЕСТВЕННО-ГЕОГРАФИЧЕСКОГО ИССЛЕДОВАНИЯ ВНУТРЕННЕГО ПЕРЕМЕЩЕНИЯ НАСЕЛЕНИЯ

В данной статье автором проведён анализ подходов и методов исследования миграционных процессов, в частности, вынужденного внутреннего перемещения населения. Проанализировав зарубежную и отечественную литературу, выявлено, что отечественные исследователи миграционных процессов пользуются традиционными методами и подходами, в то время как зарубежные учёные используют междисциплинарный инструментарий подходов и методов. Для комплексного общественно-географического исследования необходимо сочетать традиционные отраслевые и междисциплинарные методики, что позволит выявить реальные масштабы вынужденного внутреннего перемещения населения на региональном и национальном уровнях. Кроме того, использование данной методики позволит провести качественные или количественные исследования миграций, оценить масштабы миграционных процессов и выявить структурно-динамические особенности мигрантов.
}

(C) Lohvynova M., 2019 
Для исследования внутреннего перемещения населения автор предлагает использовать такие подходы: географический, системный, синергетический, информационный, исторический, демографический, экономический, юридический, социологический, психологический, индивидуальный. Автором рассмотрено использование традиционных методик общественно-географического исследования миграционных процессов. Важное значение имеют философские и общенаучные методы, в частности анализ и синтез, индукция и дедукция, наблюдение, абстрагирование и другие. Обоснована необходимость использования социологических и математико-статистических методов. При этом в зависимости от типа собранных данных, используют качественные (кодирование или контент-анализ) или количественные (статистические методы: регрессия, описательная статистика или моделирование структурных уравнений) методы. Эффективность исследования миграционных процессов повышают математические методы, в частности моделирование. В прогнозировании миграционных процессов используют следующие виды моделей: открытые или закрытые модели; дискретные или непрерывные модели; детерминированные или стохастические модели. Наиболее эффективной, на наш взгляд, является гравитационная модель Дж. Зипфа, а также различные виды регрессионных моделей.

Ключевые слова: метод, социологические методы, моделирование миграционных процессов, миграция, вынужденная миграция, общественно-географическое исследование.

Formulation of the problem. Migration processes have long been an object of study for scientists of different scientific fields, therefore, the methodological basis of their research is quite developed. However, the variety of forms and directions, features of migration processes at various levels of territorial organization require a revision of existing methods for their study. The methodology for studying migration processes can radically differ depending on their type, form, directions, structural features of migrants, etc. Methods that are excellent for studying migration in some territories do not give a complete picture of migration processes in other territories and vice versa. Studying migration processes within the country, it is necessary to study the structural and dynamic characteristics of migrants, migration factors, features of adaptation and integration of migrants in the new conditions, their socio-psychological characteristics, and interaction with the local population. All these aspects cannot be investigated qualitatively using only one group of methods. Carrying out such a comprehensive study requires careful selection of research questions, studying international and domestic experience in researching migration processes, choosing approaches and research methods that will give the most detailed picture of the object of study. The study of internal population displacement (forced migration) as a multidimensional spatio-temporal phenomenon and social process is at the junction of various scientific schools, doctrines and theories and is associated with the interests of various human disciplines (economics, sociology, demography, political science, etc.). Therefore, the study of internal population displacement requires a systematic vision and is based on the application of interdisciplinary research methods.

Analysis of previous research and publications. Today, more and more scientists emphasize the need for research on migration processes based on an interdisciplinary approach. According to R. Alba and V. Nee, forced migration is a social process in which economic factors, human agencies and social networks play an important role, should be an international and interdisciplinary event [15, p. 828].

S. Castles argues that the theory of migration processes should analyze the movement of people in terms of their multilayer relationships with other trends in a globalized world. Thus, macroeconomic trends in the economy, political and military questions are crucial for the restructuring of the global space in which people move [17]. The methodology of migration studies should work in an interdisciplinary direction, using the findings of the study of migration by scientists of other disciplines. Migration researchers should take a holistic approach, linking case studies of broader aspects of the transformation of migration and its roots in the social sphere [18].

S. Zapadniuk believes that the analysis of migration processes cannot be carried out only on the basis of the isolated application of certain methods. One group of methods allows you to analyze the features of migration flows (methods of mathematical statistics), and the other allows you to assess the objective conditions and factors underlying the migration (methods of factor analysis), the third allows you to identify motives for movement (sociological methods), and together they allow to reveal the essence of migration processes, the mechanism for controlling this phenomenon [2].

A great contribution to the development of methods for studying migration and its measuring indicators was made by V. Perevedentsev [8]. He described such indicators as the number of arrivals and departures, the migration balance; a relative measurement of these values is intensity indicators; the ratio between the influx and outflow of the population, later called the indicator of the effectiveness of the migration process; indicators of migration flows between districts and settlements. He also demonstrated the possibility of developing these indicators for various sections of the demographic and social structures of the population.

The development of theoretical and methodological aspects of migration processes in the context of sociological science was carried out under the guidance of $T$. Zaslavskaya. The priority research direction was the analysis of rural population migration to cities based on a systematic approach. T. Zaslavskaya first began to study migration not only by statistical, but also by sociological methods - from the standpoint of migration behavior [5].

Understanding the differences in population migration and migration mobility as one of the stages of the migration process led to the need for a fundamental methodological and terminological clarification of these categories, which was made by T. Zaslavskaya and L. Rybakovskyi in the concept of the three-stage migration process [11].

Employees of the Ptoukha Institute for Demography and Social Studies of the National Academy of Sciences of Ukraine under the leadership of E. Libanova developed a Program for a sample population survey on labor migration. The main research tools include question- 
naires for the survey and a methodological guide for the interviewer on the organization and methodology of the study. The methodology is based on a study of households in 14 regions of Ukraine [5].

L. Niemets, M. Lohvynova, O. Suptelo proved the need to replenish the methodological apparatus of human geography through the use of methods of related sciences, in particular sociology. The authors substantiated the importance of using sociological methods at different stages of the socio-geographical study of forced migration: at the stage of collecting information, processing and interpreting it [19].

Mathematical methods, in particular, modeling of migration processes, were widely used by Western scientists in the last century. The first to use mathematical methods (gravity models) to study the migration processes of A. Smith [23]. To forecast the migration links between Europe and North America, the Stuart-Zipf gravity model [25] is proposed. According to J. Stuart, the "demographic" force of attraction between regions is inversely proportional to the distance between them. G. Zipf, specifying the interpretation of J. Stuart, stated that the migration flow between the regions is directly proportional to the population in the region of departure and the region of arrival and inversely proportional to the square of the distance between these regions. This model was proposed to forecast migration flows and relationships. W. Reilly proposed a gravitational model in which he determined the gravity of the city as a shopping center [22]. The American economist and geographer W. Isard took into account the factor of socioeconomic behavior of the population, which directly affects migration [3, p. 124]. S. Stouffer suggested that the migration flow between regions is directly proportional to the possibilities in the region of arrival and inversely proportional to the "intermediate opportunities" arising in the process of movement between regions [24, p. 847].

O. Pozniak improved the methodology for forecasting migration processes. The methodology for forecasting migrations is based on the assessment of promising parameters of arrival and departure, as well as the age and sex structure of migrants, depending on the type and geographical direction of movements. Prediction takes place in 3 stages. At the first stage, an assessment is made of future volumes of arrival and departure, as well as the distribution of migrants by geographical directions. At the second stage, the perspective structure of migrants is assessed. The third stage of the forecast is the calculation of the migration balance by year of birth $[4$, p.182-187].

An analysis of foreign and domestic methods of studying migration processes suggests the absence of a unified methodology for their comprehensive study. At the same time, a huge number of approaches and methods require their systematization and generalization, especially in the context of their application to the study of forced internal population displacement.

Identification of previously unsettled parts of the general problem. The multifactorial nature of migration processes in the country, the complexity of relations during their formation, and the insufficient information on the extent of internal forced migration create certain dif- ficulties in regulating and managing this process. All this poses new, more complex tasks for science and makes it necessary to apply an interdisciplinary approach to assessing migration processes. In this regard, traditional approaches and methods of studying population migration cannot give a complete picture of the scale of migration, structural-dynamic and spatial characteristics of migrants. Therefore, based on a detailed study of international and domestic literature, the author has improved the methodology for studying migration processes. First, the internal displacement of the population must be investigated using both philosophical, general scientific, concrete scientific and special methods. Secondly, only an interdisciplinary scientific approach using methods of both human geography and related sciences will be able to give the most accurate picture of migration processes.

Thirdly, it is necessary to adapt mathematical (in particular modeling) and sociological methods to the study of internal displacement of the population, taking into account international experience and Ukrainian realities. Therefore, a complete review and generalization of existing methods for studying migration processes is necessary in order to identify the most suitable for a comprehensive study of internal displacement of the population.

Formulation of the purpose of the article. The purpose of the study is to substantiate the research methodology of migration processes, in particular, internal population displacement, based on the experience of previous studies. Recently, the number of studies related to population migration has increased, which requires the systematization and improvement of research methods. The key question of this scientific article is the justification of the methods that are best suited for a comprehensive study of forced migration. The objectives of the study are: analysis of foreign and domestic methods of studying migration processes, the selection of approaches and methods for a comprehensive study of internal displacement of the population, the rationale for the use of interdisciplinary methods in the study of migration.

Presentation of the main research material. The most important stage of the socio-geographical study of internal displacement of the population is the design of the study, which includes the selection and justification of research methods. The researcher must also decide which research methods he wants to use to collect data to address his research questions of interest. Such methods may include quantitative methods, such as experiments or surveys or qualitative methods, such as case studies or action studies, or possibly a combination of the two [14, 17].

In our study, a multidisciplinary approach is more suitable, which allows to use the unique strengths of each research method and generate ideas that cannot be obtained using one method. The methodology of sociogeographical research is an algorithm or procedure for the implementation of scientific knowledge of the process of internal displacement of the population, which is based on general scientific and special principles, and the goal is achieved through the use of interdisciplinary approaches, as well as a combination of philosophical, general scientific, concrete scientific and special methods. 
Among the approaches that are most suitable for studying internal population displacement are the following $[9,13]$ :

- geographical approach - considers migration processes in a spatial aspect, ensuring the complexity of socio-geographical research;

- systematic approach - migration processes are considered as a large, complex, open, multi-level subsystem of a complex demographic system of a region, which, in turn, consists of subsystems of a lower hierarchical level, and the stability of its functioning is determined by the effective activity of all elements of the region [6, pp. 39-40];

- synergetic approach - is used in the study of the constituent elements of the migration processes of the population and subsystems in the general demographic system from the standpoint of its capabilities for evolution and self-development;

- information approach - the study of the features of information exchange in the migration system [6, p. 55];

- historical approach - focuses on the historical aspects of the migration processes in the study area, tries to identify the historical factors and conditions that contributed to migration;

- demographic approach - considers the phenomenon of migration under the prism of the region's population, gender and age structure and population reproduction [12];

- economic approach - sees in the migration of the regulator of the able-bodied population, in this case, migration acts as an incentive to increase competition in the labor market;

- legal approach - analyzes the features of the legal status of various categories of migrants and is aimed at developing and improving legal norms and legislative acts;

- sociological approach - aimed at solving the problem of adaptation of migrants in the new environment;

- psychological approach - aimed at the study of psychological factors that encourage people to migrate;

- individual approach - relies on the theory of human capital and considers migration as an investment that a person uses to improve his own life.

In the study of migration processes, scientists use the full range of scientific methods for a wider presentation and analysis of this phenomenon. Among the research methods there are philosophical, general scientific and concrete scientific methods.

Among the philosophical and general scientific methods for the study of migration processes, the dialectic method, methods of analysis and synthesis, induction and deduction, description and generalization, systematization, ranking and grouping and some other methods are mainly used. This set of methods can be used when considering the theoretical concepts of forced migration, describing general trends, identifying the main causes, factors and principles of the formation and development of migration flows, while analyzing the essential properties, structures of migration processes, the relationships between its elements (table 1).

The choice of method in the study depends on the goals and objectives that the researcher sets himself. Of the concrete scientific methods, the most common in the study of migration processes are statistical and mathematical methods, mathematical modeling, sociological methods, graphical and analytical methods, cartographic methods, and demographic science methods [12].

The special methods of scientific research of internal population displacement include sociology methods. To study migration processes, quantitative and qualitative sociological methods are traditionally used. The quantitative methodological arsenal, focusing on certain general laws, is used to study objective, quantitatively measured social characteristics. Strict requirements are imposed on the sample in quantitative studies, based on probability theory and mathematical statistics, however, when conducting a survey, it is necessary to take into account the reliability of information and the subjectivity of the estimates and use interrogation methods in combination with others. Among them is a sociological survey (questionnaires and interviews).

Qualitative research methods are aimed not so much at fixing quantitative parameters as at knowing the quality of the phenomenon that makes it socially significant [1, p. 231]. These include focus groups, a biographical method, ethnographic descriptions of life paths. The express observation method is well suited for studying internally displaced people who are not concentrated locally, but live, for example, in places of compact residence of IDPs. At the analytical stage of the study, depending on the type of data collected (quantitative or qualitative), this type of analysis is used: quantitative (statistical methods: regression or modeling of structural equations) or qualitative (coding or content analysis) [19].

Quantitative methods such as surveys, descriptive statistics, and regression are used to analyze data at the macro and micro levels, mainly: demographic aspects of migrants, their numbers, gender and age characteristics, employment, etc. However, qualitative methods can also be used to study some aspects of the life of migrants, such as revealing biographical data from the life of migrants, which is very popular among researchers in the field of social sciences.

I. Pribytkova calls the territorial displacement of the population a self-organizing process of social behavior of individuals, and their number - an integral indicator that reflects the effect of many factors that really attract people to a particular region. Therefore, to study migration processes as spatial systems, the author proposes to use the method of modeling spatial processes. Among the modeling methods, gravitational, regression, and also models of potentials and spatial interaction are distinguished [10].

The use of mathematical methods significantly increases the efficiency of research on migration processes, however, the methods of modeling and forecasting migration require improvement.

Since the migration process consists of several stages, the modeling method can be applied at each stage. The main stage of the migration process is displacement. Here, the simulation includes the construction of a system of indicators that comprehensively describes the structure of the migration flow. These indicators include socio-demographic (gender, age, marital status, ethnic composition, education, etc.) and socio-geographical (location, status, influence of migrants on the economic 
development and production structure of the region). The final stage of the migration process is the adaptation of immigrants to a new place of residence. The purpose of modeling in this phase is to identify the influence of migrants on the socio-economic development of certain territories.

\section{Methods of socio-geographical research of internal population displacement} (constructed by the author $[6,9,12,19]$ )

Table 1

\begin{tabular}{|c|c|c|}
\hline $\begin{array}{l}\text { Methodo- } \\
\text { logy level }\end{array}$ & Method & Methodology of using the method in the study of internal population displacement \\
\hline \multirow{3}{*}{ 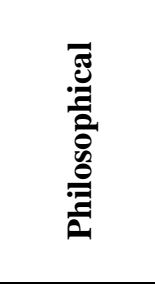 } & $\begin{array}{l}\text { Dialectical } \\
\text { method }\end{array}$ & $\begin{array}{l}\text { To identify contradictions that affect internal migration processes in Ukraine and to } \\
\text { find ways to resolve these contradictions. }\end{array}$ \\
\hline & $\begin{array}{c}\text { Induction and } \\
\text { deduction methods }\end{array}$ & $\begin{array}{l}\text { To study the internal displacement of the population at the state, regional and local } \\
\text { levels and the formation of patterns of functioning and development of forced mi- } \\
\text { gration. }\end{array}$ \\
\hline & $\begin{array}{l}\text { The method of } \\
\text { scientific abstraction }\end{array}$ & To explore the local features of the processes of internal forced migration. \\
\hline \multirow{11}{*}{ 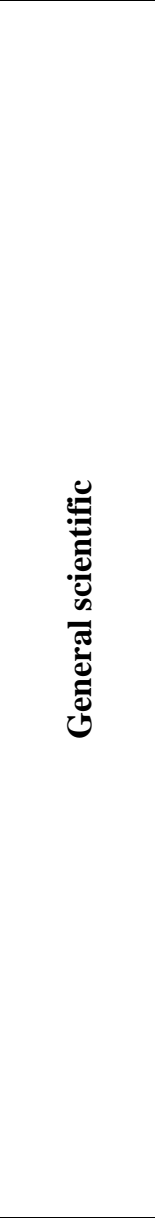 } & $\begin{array}{l}\text { Analysis and } \\
\text { synthesis method }\end{array}$ & $\begin{array}{l}\text { To highlight the features of forced migration, both in Ukraine, and at the regional } \\
\text { and local levels, taking into account certain demographic indicators in order to } \\
\text { simulate the situation and forecast the further development of this process. }\end{array}$ \\
\hline & $\begin{array}{l}\text { Generalization } \\
\text { method }\end{array}$ & $\begin{array}{l}\text { To summarize the historical features of the development of Eastern Ukraine as a } \\
\text { prerequisite for the formation of internal population displacement, determine the } \\
\text { stages of development of the research region; The method allows you to summa- } \\
\text { rize statistics on internal population displacement. }\end{array}$ \\
\hline & Description method & $\begin{array}{l}\text { To determine the basic concepts regarding the internal displacement of the popula- } \\
\text { tion, the description of the spatio-temporal features of forced migration in Ukraine. }\end{array}$ \\
\hline & Modeling method & To build a model that shows the situation of internally displaced persons. \\
\hline & $\begin{array}{l}\text { Systematization } \\
\text { method }\end{array}$ & $\begin{array}{l}\text { To systematize the received information about the object of study in the form of a } \\
\text { data system. }\end{array}$ \\
\hline & Ranking method & $\begin{array}{l}\text { To determine the place of internal displacement of the population in world migra- } \\
\text { tion processes and the place of regions in the national dimension. }\end{array}$ \\
\hline & Grouping method & $\begin{array}{l}\text { To group the factors of the placement of internally displaced persons in the East of } \\
\text { Ukraine (by quality indicators). }\end{array}$ \\
\hline & $\begin{array}{l}\text { Historical method } \\
\text { (comparative- } \\
\text { historical, } \\
\text { retrospective } \\
\text { analysis) }\end{array}$ & $\begin{array}{l}\text { To identify the historical features of the development of the research region as a } \\
\text { prerequisite for the internal displacement of the population, the characteristics of } \\
\text { the stages of development of Eastern Ukraine, the historical features of the military } \\
\text { conflict in the East of Ukraine; to conduct a retrospective analysis of the resettle- } \\
\text { ment of internally displaced persons. }\end{array}$ \\
\hline & $\begin{array}{l}\text { Mathematical and } \\
\text { statistical method }\end{array}$ & $\begin{array}{l}\text { To collect process and analyze primary statistical materials, conduct cluster and } \\
\text { factor analysis to reflect the real situation with internally displaced persons. }\end{array}$ \\
\hline & $\begin{array}{l}\text { Formalization } \\
\text { method }\end{array}$ & $\begin{array}{l}\text { To display the form, structure, content, characteristics of the course of migration } \\
\text { processes. }\end{array}$ \\
\hline & Graphical method & $\begin{array}{l}\text { To visualize the results of the study, a visual representation of the processes and } \\
\text { phenomena in order to further analyze the information received. Identification of } \\
\text { patterns, relationships between the analyzed indicators in the space-time continu- } \\
\text { um. }\end{array}$ \\
\hline \multirow{5}{*}{ 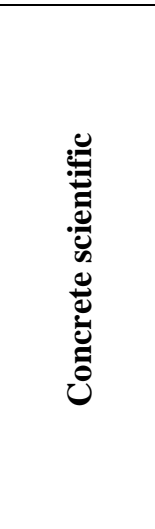 } & $\begin{array}{l}\text { Comparative } \\
\text { geographic }\end{array}$ & $\begin{array}{l}\text { To compare the intensity of the development of internal population displacement in } \\
\text { historical and territorial aspects. }\end{array}$ \\
\hline & $\begin{array}{l}\text { GIS modeling; } \\
\text { modeling of } \\
\text { migration processes }\end{array}$ & $\begin{array}{l}\text { To collect and process data to establish patterns of development of socio- } \\
\text { geographical processes, while modeling the further situation with internally dis- } \\
\text { placed persons. }\end{array}$ \\
\hline & Forecasting method & $\begin{array}{l}\text { To forecast the potential return of internally displaced persons to their previous } \\
\text { places of residence. }\end{array}$ \\
\hline & $\begin{array}{l}\text { Cartographic method } \\
\text { and cartographic } \\
\text { modeling }\end{array}$ & $\begin{array}{l}\text { To mapping and visualization of the spatio-temporal features of the development of } \\
\text { processes of internal population displacement. }\end{array}$ \\
\hline & $\begin{array}{l}\text { Sociological methods } \\
\text { (interviews, focus } \\
\text { groups, survey) }\end{array}$ & $\begin{array}{l}\text { To identify individual and psychological characteristics of internally displaced } \\
\text { persons. }\end{array}$ \\
\hline
\end{tabular}


The variety of modeling problems corresponds to the variety of methods used to solve them. For example, D. Bartolomyu gives the following principles for classifying population displacement patterns [1]:

open or closed models - depending on which relationships of the system in question are taken into account: external or inherent in the system;

discrete or continuous models - depending on the time parameter in the model;

deterministic or stochastic models - depending on whether random fluctuations to which migration indicators are subject (or are not taken into account) are taken into account.

G. Zipf proposed the so-called gravitational model for predicting migration volumes between regions, which was based on the provisions of the gravitational law of spatial interaction, according to which the "demographic" force of attraction between regions is inversely proportional to the distance between them. This model has the following form [25]:

$$
\mathrm{M} i j=G \frac{P i * P j}{R_{i j}^{2}}
$$
$\mathrm{i}$ and $\mathrm{j}$

where $\mathrm{Mij}$ - the number of migrants between points

$P i$ - population in $\mathrm{i}$;

$P j$ - population in $j$;

$R i j^{2}$ - distance between cities $i$ and $j$;

$G$ - statistically calculated constant "gravity".
S. Stouffer believed that the number of people who move a certain distance is inversely proportional to the number of obstacles and directly proportional to the opportunities that open to migrants [24, pp. 846-847]. Stouffer called obstacles all circumstances that impede migration processes (travel costs, lack of information, negative attitude of local people to visitors, political and legislative restrictions). The distance and population of the two territories is not the main thing, which determines the volume of migration between them, since it is necessary to take into account various factors that affect the likelihood of migration [24]:

$$
I i j=G \frac{P i * P j}{\sum_{n-1}^{j-1} X n}
$$

where $I i j$ - the magnitude of the flow of migrants between points i and j;

$P i$ - population in $i$;

$P j$ - population in $\mathrm{j}$;

$\mathrm{Xn}$ - number of opportunities at the n-intermediate point;

$n=1,2,3 \ldots \ldots . j-1$.

In the study of migration processes, regression models are often used to provide practical conclusions regarding specific factors and the degree of their influence on territorial population displacement. When studying the spatial aspects of the internal displacement of the population, the spatial localization of migrants, it is most effective to use cartographic modeling.

\begin{tabular}{|c|c|c|}
\hline Indicator & The essence of the indicator & Calculation algorithm \\
\hline \multicolumn{3}{|c|}{ Absolute indicators } \\
\hline Gross migration & $\begin{array}{l}\text { characterizes the volume of migration } \\
\text { flows }\end{array}$ & $\begin{array}{l}\quad G M=\mathrm{I}+\mathrm{O} \text {, where } \\
\mathrm{I}-\text { the number of immigrants; } \\
\mathrm{O}-\text { the number of out migrants. }\end{array}$ \\
\hline $\begin{array}{l}\text { Migration balance } \\
\text { (net migration) }\end{array}$ & $\begin{array}{l}\text { characterizes migration growth (reduc- } \\
\text { tion) of the population }\end{array}$ & $\begin{array}{l}\quad N M=\mathrm{I}-0, \text { where } \\
\mathrm{I}-\text { the number of immigrants; } \\
\mathrm{O}-\text { the number of out migrants. }\end{array}$ \\
\hline \multicolumn{3}{|c|}{ Relative indicators } \\
\hline Immigration rate & $\begin{array}{l}\text { characterizes the arrival of migrants per } \\
1000 \text { people of the population }\end{array}$ & $\begin{array}{l}\qquad I M R=\frac{I}{P} * 1000, \text { where } \\
\mathrm{I}-\text { the number of immigrants; } \\
\mathrm{P}-\text { population per year. }\end{array}$ \\
\hline Emigration rate & $\begin{array}{l}\text { characterizes the departure of migrants } \\
\text { per } 1000 \text { people of the population }\end{array}$ & $\begin{array}{l}\quad O M R=\frac{O}{P} * 1000 \text {, where } \\
\mathrm{O}-\text { the number of out migrants; } \\
\mathrm{P}-\text { population per year. }\end{array}$ \\
\hline Migration efficiency rate & $\begin{array}{l}\text { characterizes specific gravity migration } \\
\text { growth (decline), the share of net } \\
\text { migration to gross migration }\end{array}$ & $M E R=\frac{I-O}{I+O} * 100 \%$ \\
\hline $\begin{array}{l}\text { General coefficient of } \\
\text { population mobility } \\
\text { (coefficient of intensity of } \\
\text { migration turnover) }\end{array}$ & $\begin{array}{c}\text { characterizes the intensity of } \\
\text { movement (the number of arrivals and } \\
\text { departures) of migrants per } 1000 \\
\text { people of the population }\end{array}$ & $\begin{array}{l}\quad G C P M=I M R+O M R, \text { where } \\
I M R-\text { immigration rate; } \\
O M R-\text { emigration rate. }\end{array}$ \\
\hline Migrant Settlement Rate & $\begin{array}{l}\text { shows the number of people remaining } \\
\text { at their permanent place of residence } \\
\text { per } 1000 \text { persons of migration growth }\end{array}$ & $\begin{array}{l}\qquad M S R=\frac{\Sigma I-\Sigma O}{O} * 1000 \text {, where } \\
O-\text { the average number of emigrants over } \\
\text { three years; } \\
\Sigma I, \Sigma O-\text { the number of immigrants and } \\
\text { emigrants for three years. }\end{array}$ \\
\hline
\end{tabular}

The system of statistical indicators for assessing the internal displacement of the population [2, 8, 11] 
Having defined the tasks and goals of modeling, it is necessary to develop a system of indicators that reflect all aspects of the process of population displacement. Most of the indicators used in domestic models characterize the second stage of the migration process and are based on three initial components: the population of a particular territory, the number of departures, and the number of arrivals over a certain period of time. Since the regions and settlements involved in migration differ in the demographic situation and economic and geographical position, often not only the values of these components are considered, but also their specific gravities in the total population of the region (or in the size of any social or age-gender group).

Foreign and domestic literature describes up to two dozen indicators of migration, which successfully present information about the object of study [2]. In the analysis of migration processes, quantitative and qualitative indicators of this phenomenon are used. Migration indicators characterize migration processes, taking into account their scale, structure, directions, level of population mobility. S. Zapadniuk divides all migration indicators into indicators of potential migration and indicators of actual migration. The latter, in turn, are also divided into three groups: general (characterizing the aggregate indicators of migration for the territory), special (structural, characterizing the migration of specific demographic groups) and indicators of inter-district exchange (show the links between administrative units) [2].

The study of migration processes is a rather complicated process, requiring the use of both absolute and relative indicators. The absolute indicators include the number of arrivals and departures per year, the migration balance. Relative indicators include various coefficients that make it possible to more broadly interpret data on migration processes in a particular region (emigration and immigration rate, migration efficiency, migration intensity, etc.) (Table 2).

Based on the considered system of absolute and relative indicators of migration, it is possible to conduct a fairly complete and comprehensive study of the trends and patterns of internal migration processes, which cre- ates the prerequisites for the scientific substantiation of managerial decisions for the settlement of migration processes at the regional and national levels.

Conclusions. Despite the available methodological tools, it is necessary to pay special attention to the development of research methods for migration processes, especially at the regional and local levels. The internal displacement of the population, as a component of migration processes, is best studied using interdisciplinary approaches: geographical, systemic, synergetic, informational, historical, demographic, economic, legal, sociological, psychological, individual. Traditional in sociogeographical studies of migration processes are general scientific methods - analysis and synthesis, induction, deduction, observation, abstraction, generalization in combination with modern methods, among which the most used are system analysis and synthesis, mathematical modeling and the like. Concrete scientific and special methods are used, such as: comparative geographical, cartographic and cartographic modeling, mathematical and statistical, GIS modeling, sociological. Mathematical and statistical and modeling methods involve the use of a system of indicators that reflect all aspects of the process of population displacement. In the analysis of migration processes, quantitative and qualitative indicators of this phenomenon are used. They characterize migration processes, taking into account their scale, structure, directions, level of population mobility. All indicators of migration processes are divided into absolute and relative (coefficients).

Using only traditional methods does not allow conducting qualitative or quantitative studies of migrations, assessing the scale of migration processes, and revealing the structural and dynamic characteristics of migrants. Therefore, there is a need to select integrated methods, the application of which would reveal the features of the development of regional migration systems, their components and thereby determine the problems and prospects for their development. Therefore, it is necessary to replenish the theoretical and methodological apparatus of social geography based on the implementation of methods of related sciences.

\section{References:}

1. Bartolomyu, D.D. (1985). Stohasticheskie modeli socialnyh processov [Stochastic models of social processes]. Moskva: Finansy i statistika, 295 [in Russian].

2. Zapadniuk, S.O. (2011). Mihratsii naselennya Ukrainy: peredumovy, dynamika ta naslidky rozvytku [Migrations of the population of Ukraine: background, dynamics and consequences of development]. Kyiv: Akademperiodyka, 240 [in Ukrainian].

3. Izard, U. (1968). Metody regionalnogo analiza: vvedenie v nauku o regionakh [Regional Analysis Methods: An Introduction to Regional Science]. Moskva: Progress, 659 [in Russian].

4. Pozniak, O.V. (2007). Mihratsiyni protsesy v Ukraini: suchasnyi stan i perspektyvy [Migration processes in Ukraine: current status and prospects]. Uman, 276 [in Ukrainian].

5. Naselennya Ukrainy. Trudova emihratsiya v Ukraini (2010) [The population of Ukraine. Labor emigration in Ukraine]. Kyiv: In-t demografii ta sotsialnykh doslidzhen im. M.V. Ptukhy NAN Ukrainy, 233 [in Ukrainian].

6. Niemets, K.A., \& Niemets, L.M. (2014). Teoriya i metodologiya geografichnoi nauky: metody prostorovoho analizu [Theory and Methodology of Geography: Spatial Analysis Methods]. Kharkiv: KhNU imeni V.N. Karazina, 172 [in Ukrainian].

7. Niemets, K.A. (2009). Modelyuvannya trayektorii rozvytku regionalnykh sotsiogeosystem Ukrainy [Modeling the development path of regional socio-geosystems of Ukraine]. Chasopys sotsialno-ekonomichnoi geografii - Human Geography Journal, 7(2), 66-80 [in Ukrainian]. 
8. Perevedentsev, V.I. (1975). Metody izucheniya migratsii naseleniya [Methods of studying population migration]. Moskva: Nauka, 31 [in Russian].

9. Pistun, M.D. (1996). Osnovy suspilnoi geografii [Fundamentals of Human Geography]. Kyiv: Vyshcha shkola, 231 [in Ukrainian].

10. Pribytkova, I.M. (2009). Prostranstvennaya samoorganizatsiya naseleniya: teoretiko-metodologicheskie predposylki issledovaniya [Spatial self-organization of the population: theoretical and methodological background of the study]. Sotsiologiya: teoriya, metody, marketing - Sociology: theory, methods, marketing, 4, 84-98 [in Russian].

11. Rybakovskyi, L.L. (2001). Stadii migratsiynoho protsesu [Stages of the migration process]. Migratsiya naselennia - Population migration, 5, 125 [in Russian].

12. Topchiyev, O.H. (2005). Suspilno-geografichni doslidzhennya: metodologiya, metody, metodyky [Human geography researches: methodology, methods, techniques]. Odesa: Astroprynt, 631 [in Ukrainian].

13. Shabliy, O.I. (2001). Suspilna geografiya: teoriya, istoriya, ukrainoznavchi studii [Human geography: theory, history, ukrainian knowledge]. Lviv: LNU im. I. Franka, 744 [in Ukrainian].

14. Homra, A.U. (1979). Migratsiya naseleniya: Voprosy teorii, metodiki issledovaniya [Migration: Issues of Theory, Research Techniques]. Kyiv, 148 [in Russian].

15. Alba, R., \& Nee, V. (1997). Rethinking Assimilation Theory for a New Era of Immigration. International Migration Review, 31(4), 826-874.

16. Benmayor, R., \& Skotnes, A. (1994). On Migration and Identity. Oxford: Oxford University Press, 1-18.

17. Castles, S. (2000). International Migration at the Beginining of the Twenty-First Century: Global Trends and Issues. International Social Science Journal, 52(165), 270-271.

18. Castles, S. (2007). Twenty-first century migration as a challenge to sociology. Journal of Ethnic and Migration Studies, 33(3), 351-71.

19. Niemets, L., Lohvynova, M., \& Suptelo, O. (2019). Sociological methods in human-geographic researches: features of application. Chasopys sotsialno-ekonomichnoi geografii - Human Geography Journal, 26, 13-23. DOI: https://doi.org/10.26565/2076-1333-2019-26-02.

20. Niemets, L., Husieva, N., Pohrebskyi, T., Bartosh, O., \& Lohvynova, M. (2020). Integration of internally displaced persons of Ukraine: realities, problems, perspectives. Visnyk Kharkivskoho natsionalnoho universytetu imeni V.N. Karazina, Ceriya "Geologiya. Geografiya. Ekologiya” - Visnyk of V.N. Karazin Kharkiv National University, series “Geology. Geography. Ecology”, (51), 140-157. DOI: https://doi.org/10.26565/2410-7360-201951-10.

21. Pribytkova, I.M. (2007). Cartographical Modeling as a Statistical Method for Monitoring of a Spatial Behaviour of Population. Recent Advances in Stochastic Modeling and Data Analysis. World Scientific Publishing Co. Pte. Ltd.

22. Reilly, W.J. (1953). The law of retail gravitation. New York: Pilsbury Publishers, 75.

23. Smith, A., Campbell, R.H., \& Skinner, A.S. (1976). An inquiry into the nature and causes of the wealth of nations. Oxford: Clarendon Press, 535.

24. Stouffer, S.A. (1940). Intervening Opportunities: A Theory Relating Mobility and Distance. The American Sociological Review, 6, 845-867. Retrieved from http://www.jstor.org/ stable/2084520 23.

25. Zipf, G.K. (1950). Human Behavior and the Principle of Least Effort. The Economic Journal. Retrieved from http://www.jstor.org/stable/2226729.

Надійшла до редколегї 11.10.2019 р.

\section{Про автора:}

Марина Логвинова - аспірант кафедри соціально-економічної географії і регіонознавства, Харківський національний університет імені В.Н. Каразіна, Україна, logvinova_mari94@ukr.net, https://orcid.org/0000-0003-3190-710X

\section{Об авторе:}

Марина Логвинова - аспирант кафедры социально-экономической географии и регионоведения Харьковского национального университета имени В.Н. Каразина, Украина, logvinova_mari94@ukr.net, https://orcid.org/0000-0003-3190-710X 